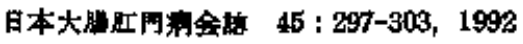

\title{
部例蝍告 I
}

\section{同胞（兄弟）に発生した Crohn 病}

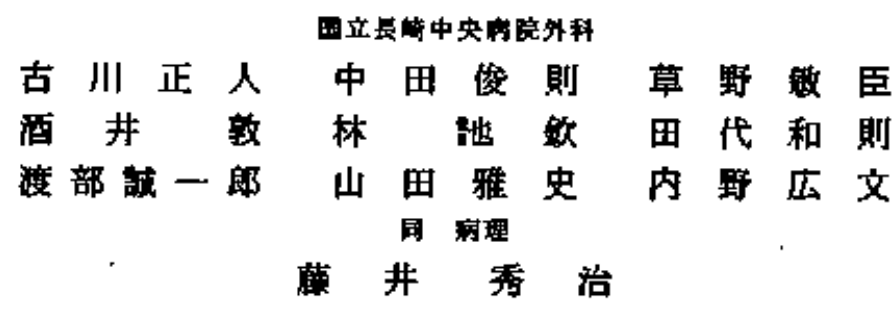

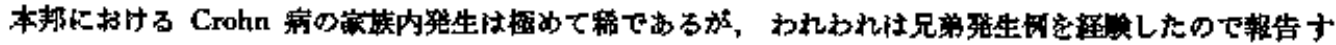

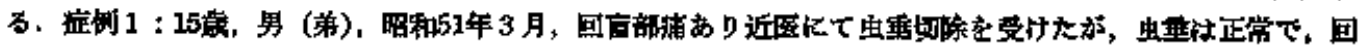

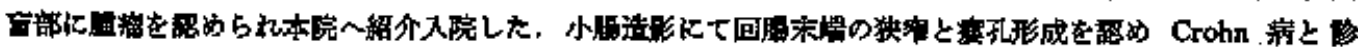

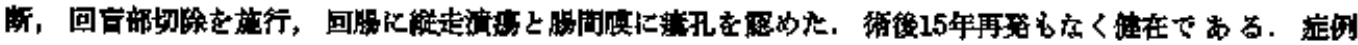

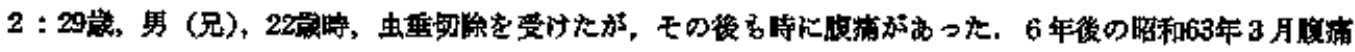

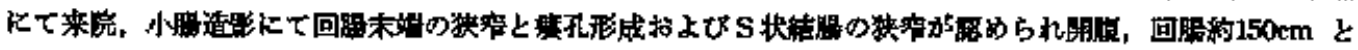

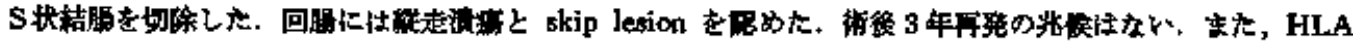

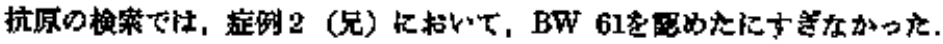

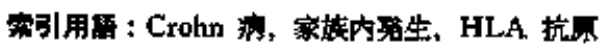

I.はじに

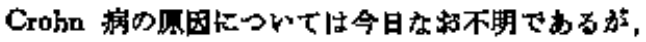

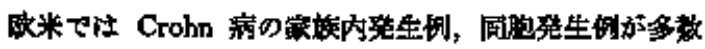

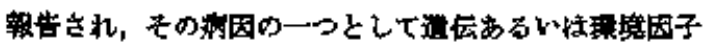
の存在が南要視されでいる. 最近本邦に蛙いです Crohn 病患者数注增加の傊向にあり，決して稀な疾患ではなく

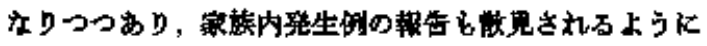
放充.

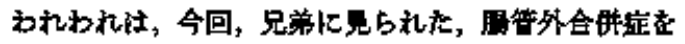

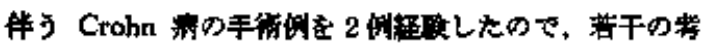
察を如えて坏告十る。

\section{II. 定 调}

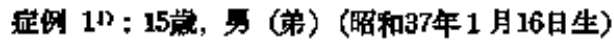

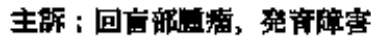

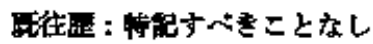

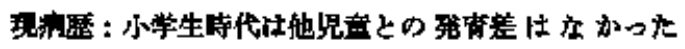

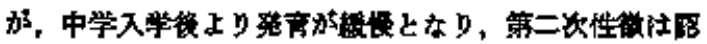
由られ加布。

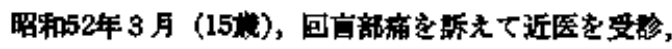

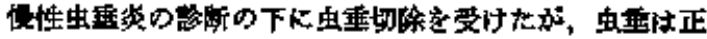

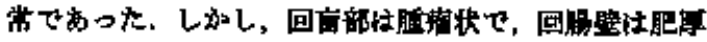

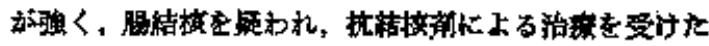

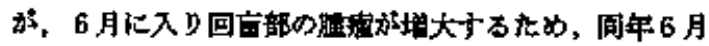
27日，本院外科入紹介，入院と市った。

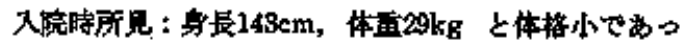

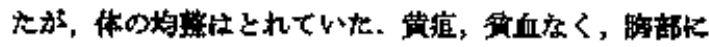

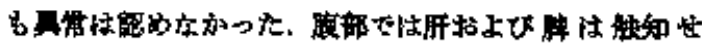

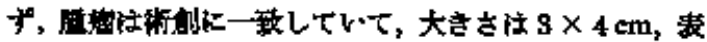

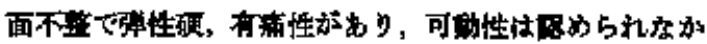
$\rightarrow$.

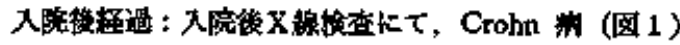

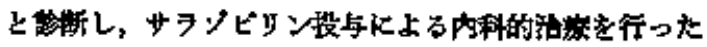

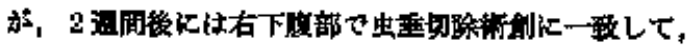

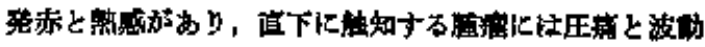

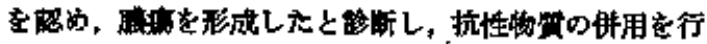

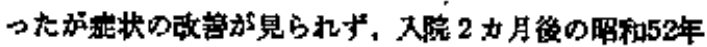

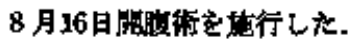

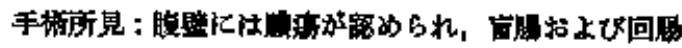

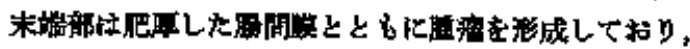

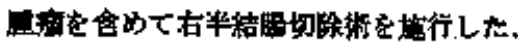




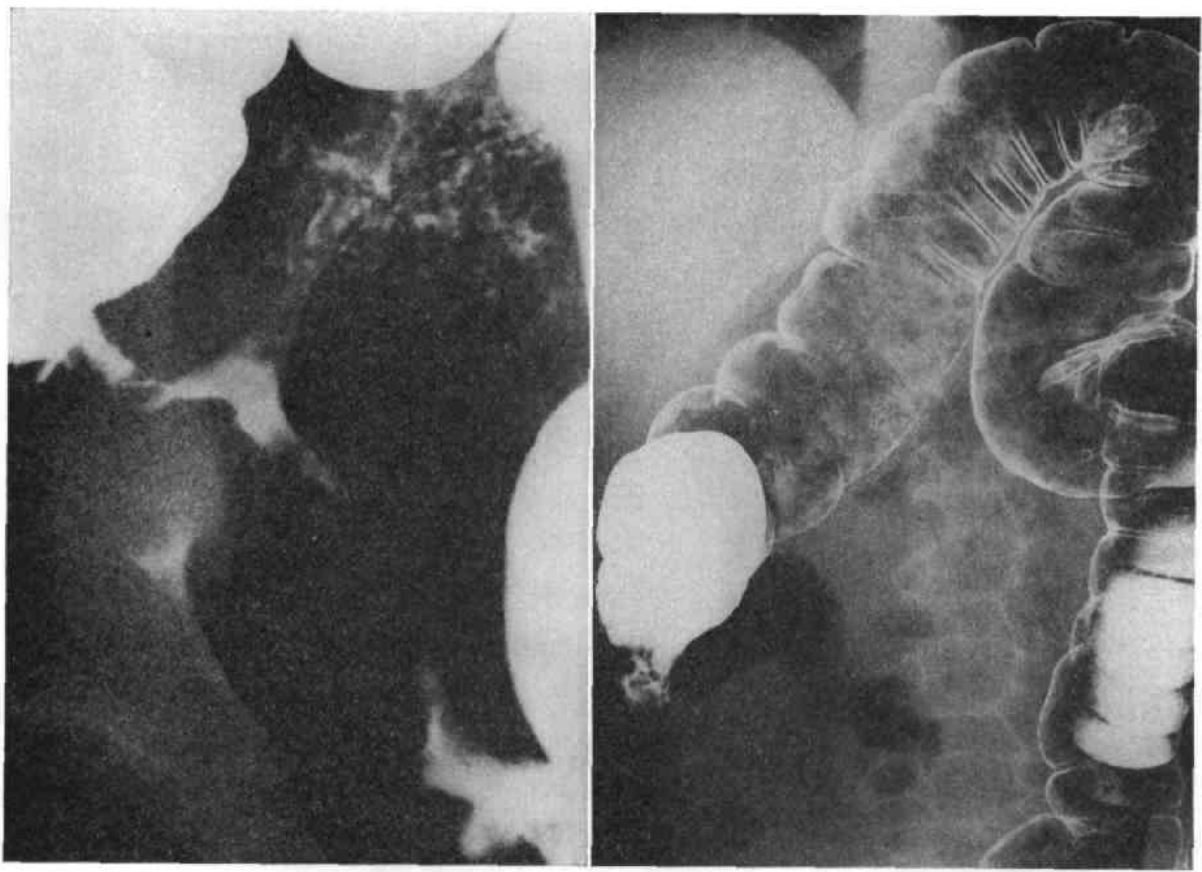

図 1 症例 1 左: 経口小腸造影, 小腸腹壁㾑孔, 右 : 注腸造影, 上行結鳰㹟窑
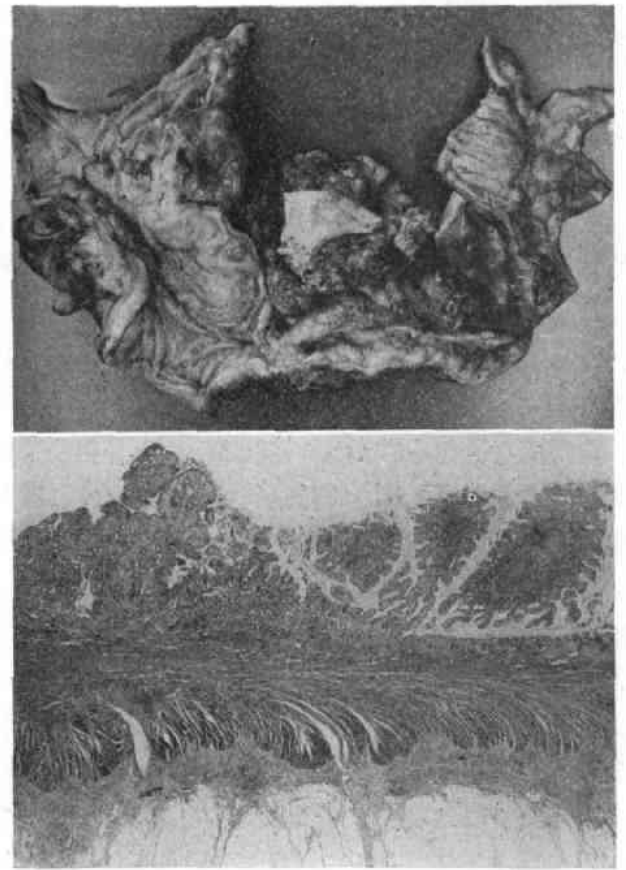

図 2 症例 1 上: 切除標本肉眼所見 下：組織学的兹見

切除標本の肉眼的所見 (図 2 上) : 回腸切除端か5 盲 晹にかけて縦走性潰瘍がみられた。涨窄は回腸，盲腸と むにあり, そこには著明な壁の肥厚があり, 狭寉した回 腸の晹間膜に潈孔を認め, 腹壁の膿痽と交通していた。
また盲腸には炎症性ポリポージスが認められた。

切除標本の組織学的所見 (図 2 下) : 顕微鏡的には,縦 走潰癌は UL II $\sim$ IVで, 回腸, 盲腸の各所で穿通し, リンバ球，プラスマ細胞の全層性の侵润とともに，組織 球，異物巨細胞を伴う膿瘍の形成が著明であった。

回腸末端は，中等度の結腸のパネート細胞化がみられ る炎症性ポリポージスとリンバ腹胞梯構造を伴う全層性 の炎症像と粘膜板の肥厚拉よび乱れを示している. 滤胞 リンパ節には肉芽腫の形成はなく，滤胞の腫大のみであ った.

術後経過 : 術後経過は良好で, 1 力月後に軽快退院, その後の発育は順調で, 体重も正常に復㸟し, 15年後の 現在, 再発の徵なく健在である.

症例 $2: 29$ 歳, 男 (兄) (昭和 33 年 6 月 21 日生)

主訴 : 腹痛, 両下肢壊瘨性澧皮症.

既往歷 : 21 歳十二指腸潰瘍 (内科的治痗).

現病歷 : 23 歲時 (6 年前)近医にて虫重切除を受けた. その後, 1 年, 3 年, 5 年後にイレウスを生し, その都 度保存的治㙩を受けていた。 6 年後の昭和 63 年 1 月中旬 より再び腹痛があり，軽快しないため，1月21日イレウ スの診断の下に本院一紹介入院となった。

入院時現应 : 身長 $173 \mathrm{~cm}$, 体重 $55 \mathrm{~kg}$, 体格中等度, 黄 㾝なく, 賓血もみられない, 胸部に異常なく, 腹部では 肝抽よび脾を触知せず，虫垂切除痕があり，下腹部には 胆蠕動不榣を認め, また両下肢に膿皮症を認めた。 


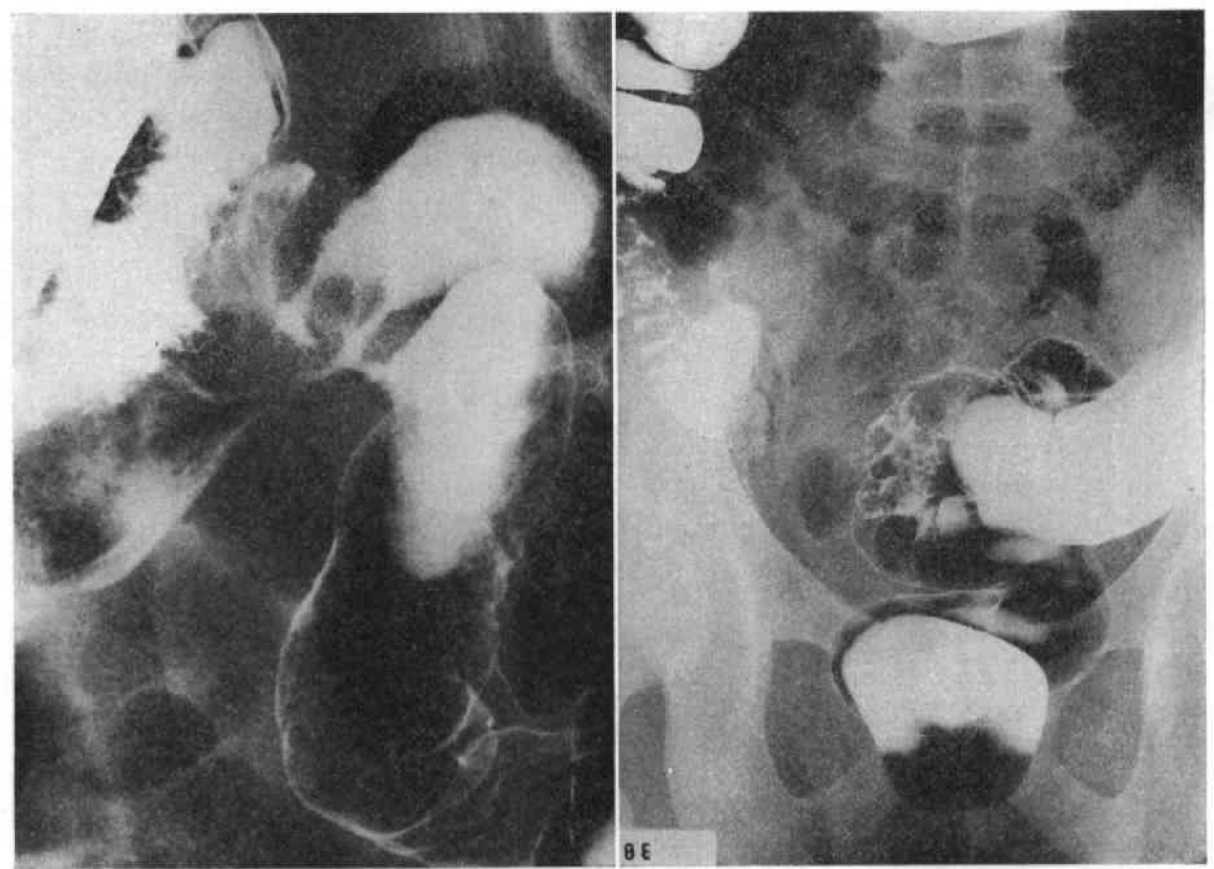

図 3 症例 2 注渴造影 左: 回盲部狭窄, 右: $\mathrm{S}$ 状結腸部澧㾇形成

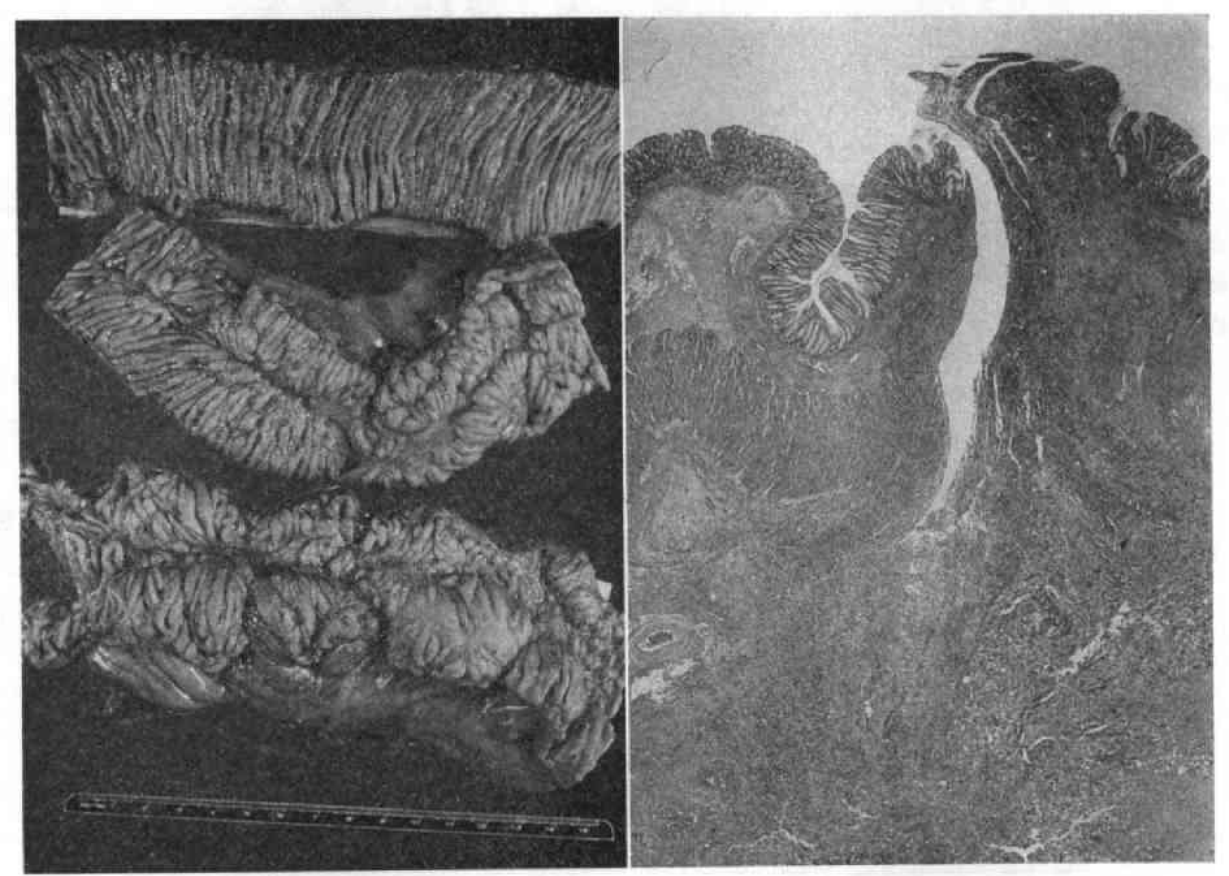

図 4 症例 2 左: 切除標本肉眼所見, 右: 組織学的所見

入院後释過 : 入院後, X線検査にて Crohn 病と㟝断 し(図 3),IVH，サラゾピリン投与にて経過钼察した が腹痛は消失せず， 3 力月後の昭和 63 年 3 月 1 日，開腹 術を施行した.

手術所見 : 回腸は回腸末端部より約 $10 \mathrm{~cm}$ のところか
ら手拳大の腫㾇を形成し, $\mathrm{S}$ 状結腸と強く痣着してい た. さらに, 約 $1 \mathrm{~m}$ 離れた回腸に約 $40 \mathrm{~cm}$ にわたって小 腸壁の肥厚が認められ、これ含めて小腸を約 $1.5 \mathrm{~m}$ 切除 し, 同時に S 状結腸切除術を施行した.

切除標本の肉眼所見 (図 4 左): 回腸の各所に 縦走潰 


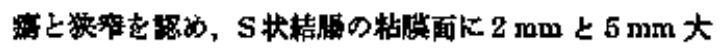
の2图の暗争色シープ状のいのがみられた.

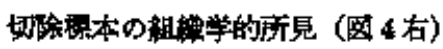

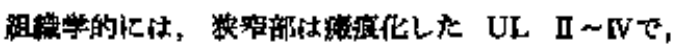

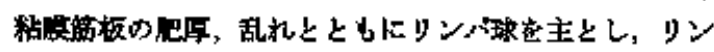

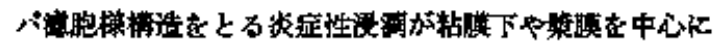

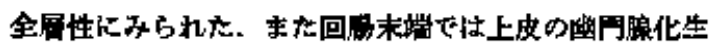

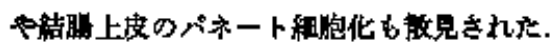

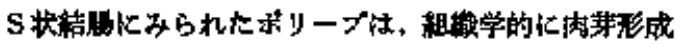

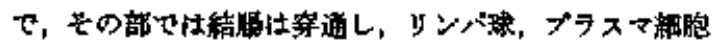

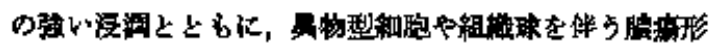

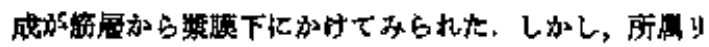

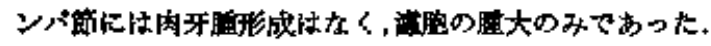

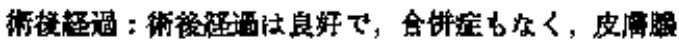

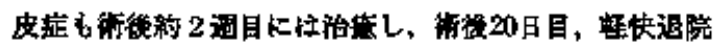

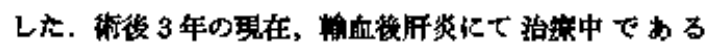

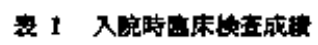

\begin{tabular}{|c|c|c|}
\hline & 应调 1 (塏) & 堙为 2 (兄) \\
\hline \multicolumn{3}{|l|}{ 类庭娦 } \\
\hline 赤计住光音 & $43 \mathrm{~mm} / \mathrm{h}$ & $35 \mathrm{~mm} / \mathrm{h}$ \\
\hline $\operatorname{CAP}$ & $4(+)$ & $6(+)$ \\
\hline 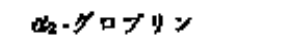 & $14.1 \%$ & \\
\hline 白血理理多 & 6,600 & 13,000 \\
\hline \multicolumn{3}{|l|}{ 鲜㕕 } \\
\hline 由色祖球少 & $11.2 \mathrm{~g} / \mathrm{dl}$ & $10.5 \mathrm{~g} / \mathrm{dr}$ \\
\hline 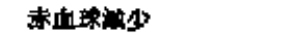 & 504 万 & 604 万 \\
\hline 血神制洁少 & & $20 \& \mathrm{c} / \mathrm{dl}$ \\
\hline \multicolumn{3}{|l|}{ 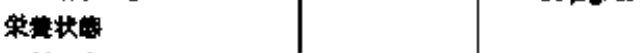 } \\
\hline 低社白血恧 & $7.2 \mathrm{~g} / \mathrm{dl}$ & $6.5 \mathrm{~g} / \mathrm{d}]$ \\
\hline 任厂见フン县㱏 & $2.68 \mathrm{~g} / \mathrm{dl}$ & $3.8 \mathrm{~g} / \mathrm{dl}$ \\
\hline 低コレステロール血宝 & $171 \mathrm{~g} / \mathrm{dl}$ & $96 \mathrm{mg} / \mathrm{d}]$ \\
\hline 殹カルシウム血庢 & $4.5 \mathrm{meg} / 1$ & 8.7 meq $/$ \\
\hline \multicolumn{3}{|l|}{ 兔龙原应 } \\
\hline lg-o $(872-1998)$ & $1,480 \mathrm{mc} / \mathrm{dl}$ & 1,6a7 $\mathrm{mg} / \mathrm{d} 2$ \\
\hline $\mathrm{Jg}-\mathrm{A}(101-427)$ & $470 \mathrm{mg} / \mathrm{dl}$ & $469 \mathrm{~m} / \mathrm{d} / \mathrm{d}]$ \\
\hline $\lg -M(44-2 J 3)$ & $\mathrm{JBO} \mathrm{mg} / \mathrm{d} \mathrm{I}$ & $270 \mathrm{mg} / \mathrm{d}$ \\
\hline
\end{tabular}

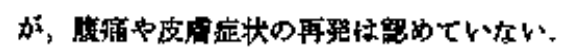

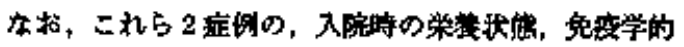

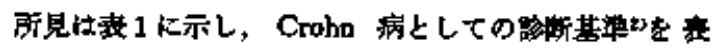
2, 管本合并空について时图 5 左右に示した。

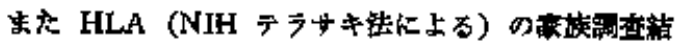
果䘮固 6 に示した.

\section{III. 䔁}

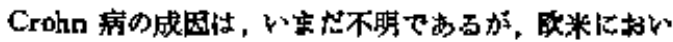

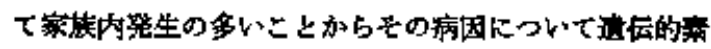

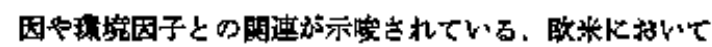

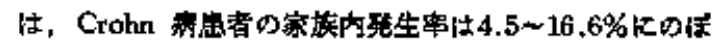

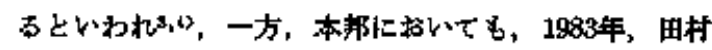

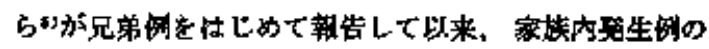

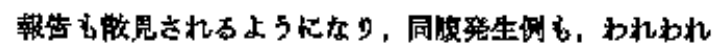

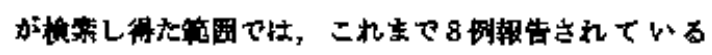

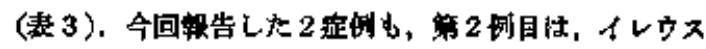

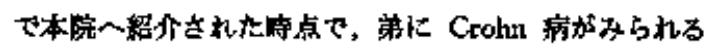

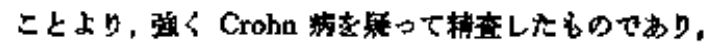

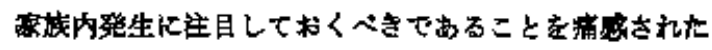
ものである.

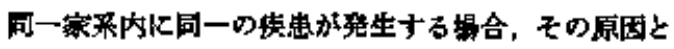

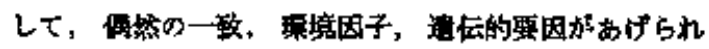
ธ.

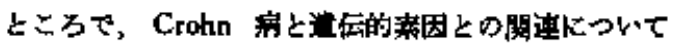

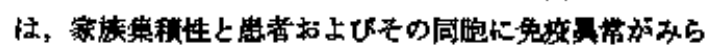

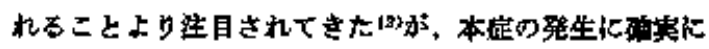

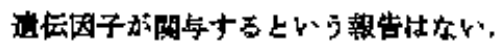

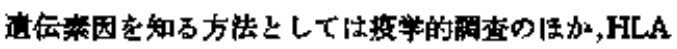

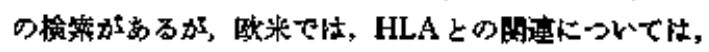

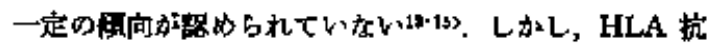

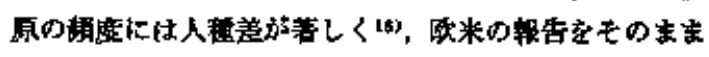

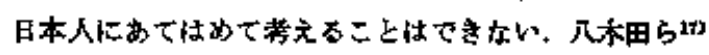

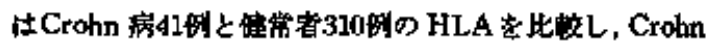

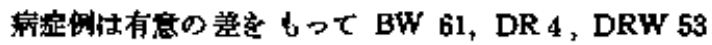

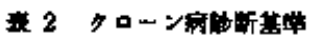

\begin{tabular}{|c|c|c|c|}
\hline & & 湿制 1 (部) & 且明2 (兄) \\
\hline 1) & 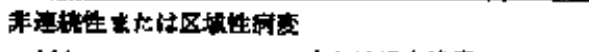 & + & + \\
\hline 2) & 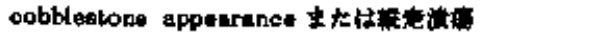 & + & + \\
\hline 3) & 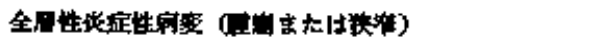 & + & + \\
\hline 4) & 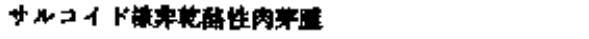 & - & - \\
\hline 5) & 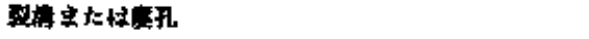 & + & - \\
\hline 6) & 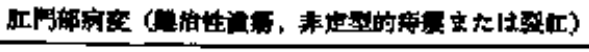 & - & - \\
\hline & 告安 & 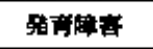 & 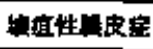 \\
\hline
\end{tabular}



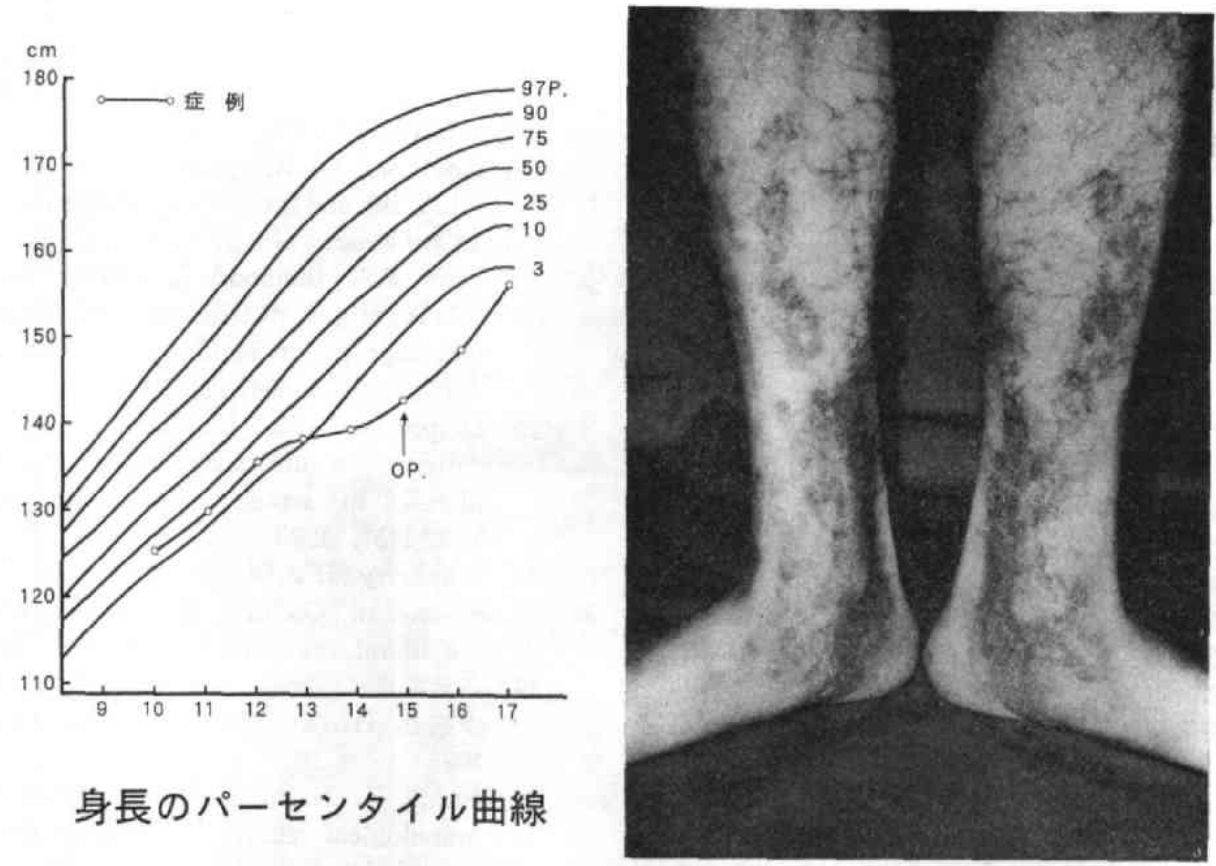

\section{身長のパーセンタイル曲線}

図 5 腸管外合併症 左: 症例 1 , 発育曲線, 右: 症例 2 , 两下肢膘皮症

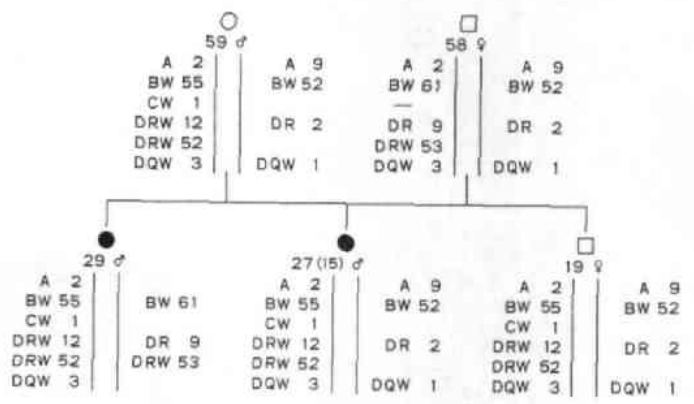

図 6 HLA 家族調查

の出現頻度が高く，有意の差はないが BW 51の出現頻 度が高い傾向がみられると報告し，Fujita ら ${ }^{18)}$ は，62例 について検討し, BW 46, BW 51, DR 4, DR 5 が 有意に高いと報告している，われわれの症例では，これ まで本邦にて Crohn 病と関連ありと報告された HLA 抗原では, わずかに症例 2 (兄) に BW 61を認めたにす ぎなかった。

最近, Crohn 病が本邦においても增加しており, 今 後, 家族内発生例の集積を行い, 病热の解明に努める必 要があると思われ報告した。

\section{IV. 結晤}

Crohn 病の兄弟発生例を経験した。兄は壊疽性膿皮 症を，弟は第二次性徽をみない発育障害を合併したか゚， 何れる原発策の切除後軽快した. さらに, 家族の HLA
表 3 本邦におりるクローン窝同腹発生例の報告洌

\begin{tabular}{|c|c|c|}
\hline 報告者 & 般告年 & 血綬関係 \\
\hline 田村 $5^{51}$ & 1983 & 兄一弟 \\
\hline 川満ら61 & 1985 & 㚴一弟 \\
\hline 水野ら 71 & 1986 & 兄一妹 \\
\hline 桶液ら ${ }^{81}$ & 1987 & 兄一弟 \\
\hline 确渡 $5^{81}$ & 1987 & 峬一弟 \\
\hline 久保 $5^{91}$ & 1987 & 兄一弟 \\
\hline 築野 5 101 & 1988 & 兄一弟 \\
\hline 林 $5^{111}$ & 1989 & 峬一弟 \\
\hline 自臨例 & 1991 & 兄一弟 \\
\hline
\end{tabular}

抗原を測定したので，若干の考察を加え報告した．

(HLA 抗原の测定を行って頂いた本院臨床㭘查科, 長友正澄氏に深䔏の时意を表す）

\section{文献}

1) 向原茂明, 伊藤瑞子, 伊藤新一郎ほか：思春期 前後のクローン病の 2 症例. 小児外科 12 : 701-705, 1980

2）山形敌一, 渡辺 晃：I. 概念と病彭断基淮. 日本消化器病学会クローン病檢柇委员会編, ク ローン病, 東京, 医学図萻出版 KK, 1987, P 2-5

3) Meyberry JF, Rhodes J: Familial prevalence of inflammatory bowel disease in rela. tives of patients with Crohn's disease. $\mathrm{Br}$ Med J $12: 84,1980$ 
4) Weterman IT, Pena AS : Familial incidence of Crohn's disease in the Netherland and a view of the literature. Gastroenterology $86: 49-462,1984$

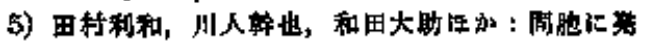

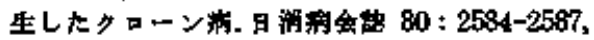
1983

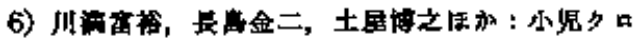

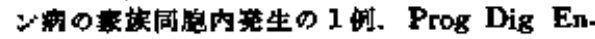
dosc 36 : $322-325,1985$

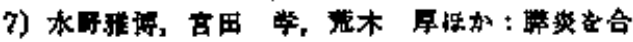

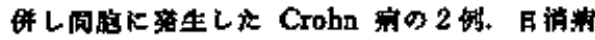
숖ㅇ $83: 1192-1198,1986$

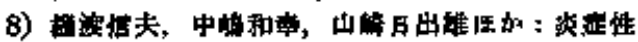

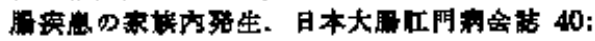
889-893, 1987

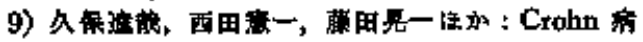

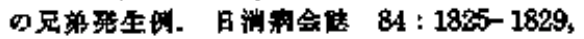
2987

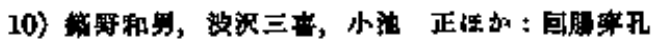

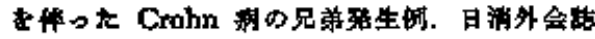
$21: 2439-2442,1989$

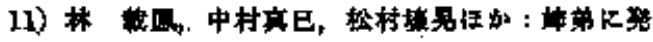

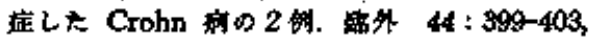
1989

12) Kraft SC, Kirsner JB: The immunology of ulcerative colitis and Crohn's disense. Edited by Kistener JB, Shorter RG. Inflammatory Bowel Desense. A Lea \& Febiger, Philadelphia, 1975, P60-80

13) Holdstock G, Macpharson B, Beeken WL: HLA BB and granuloma formation in Crohn's disense. Gut 23 : 600-602, 1982

14) Pena AS, Biemond I, Kuiper G, et al : HLA antigen distribution and HLA haplo. type segregation in Crohn's disense. Tissue Antigens $16: 56-61,1980$

I5) Delpre H, Kadish $U$, Garit E, et as : HLA antigens in ulcerative colitis and Crohn's disease in Istael. Gastroenterolgy 78: 1452-1457, 1980

16.) Mayberry JF, Rhodes J : Epidemiological sspects of Crohn's disease. A review of the literature. Gut $25: 886-889,1984$

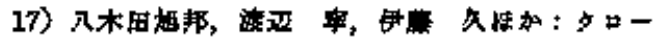
ン消と HLA. 医のあお $135: 669-670$, 1985

18) Fujite $K$, Naito $S$, Olcabe $N$, al : Immunological studies in Crohn's disease. I. Association with HLA systems in the Japanese. J Clin Lab Immunol $14: 99-102$, 1984 


\section{Crohn's Disease in Sibling}

M. Furukawa, T. Nakata, T. Kusano, T. Sakai, Y. Lin, K. Tashiro, S. Watabe and M. Uchina

Department of Strgery, Nagasaki Chuo National Hospital, Nagasaki

H. Fujiji

Department of Pathology, Nagasaki Chuo National Hospital, Nagasaki

Althogh familial incidence of Crohn's disease is very low in Japan, in our hospital two case of this disease in siblings were found.

Case 1: A 15-year-old male (younger brother). In March 1976 be had a pain in the ileocecal region and underwent appendectomy. However, the appendix wes normal, and s a tumor was found in the lleocecal region. An upper GI series indicated a stricture and a fistulation in the terminal region of the ilemm; the patient was diagnosed as having Crohn's disease. A celiotomy was done and the ileocecal resion was resected. The excised specimen revealed a longitudinal ulcer in the ileum and a fistule in the mesentery. The patient has shown no signs of recurrence and is in good health today, 15 years after the operation.

Case 2: A 29-year-old male (older brother). The patient recieved appendectomy seven years ago (at age 22). He has admitted to our hospital in March 1988 with abdominal qain, and was given barium enema which revealed a stricture and a fistulation in the terminal region of the ileum, as well as a stricture in the sigmoid colon. As his young brother had Crohn's disease, we suspected it in this patient also. Resection of $150 \mathrm{~cm}$ of the ileum as well as the sigmoid colon were done. The excised ileum showed a longitudinal ulcer and skip lesions. The patient has shown no signs of recurrence, three years after the operation.

A study of the HLA antigen revealed that among, all the HLA antigen reported in Japan to have a correlation with Crohn's disease, the only BW-61 was in Case 2 (older brother). 